\title{
Estimating surface moisture availability for evaporation \\ on bare soil from routine meteorological data and its parameterization without soil moisture
}

\author{
Tomoyoshi HIROTA*, and Masato FUKUMOTO** \\ *National Agricultural Research Center for Hokkaido Region, NARO, \\ Sapporo, Hokkaido 062-8555, Japan \\ **National Institute for Rural Engineering, NARO, Tsukuba, Ibaraki 305-8609, Japan
}

\begin{abstract}
Surface moisture availability is the most important parameter for estimating evaporation from bare soil using the bulk transfer method. In this study, we developed a simple method for the estimation and parameterization of surface moisture availability over a period ranging from 10 days to several months on bare soil using only routine meteorological data without using sensible and latent heat flux and soil moisture data. If the daily mean soil temperature is observed with other routine meteorological data of daily values (air temperature, solar radiation, precipitation, wind speed, humidity, etc.), surface moisture availability can be estimated by using a simple soil temperature model without using the sensible and latent heat flux observation data. The simple soil temperature model is composed of the heat balance equation at the ground surface, bulk transfer method and modified version of the force-restore model for estimating daily mean soil temperature. The estimation period of surface moisture availability ranges from 10 days to several months according to precipitation conditions that reflect soil wetness. The antecedent precipitation index $(A P I)$ is an effective indicator by which the soil wetness condition can be judged without using soil moisture. This enables classification of proper estimation periods of surface moisture availability. The surface moisture availability is estimated by minimizing the sum of the squares of the residual between the observed value of the daily mean soil temperature and the calculated value under the estimation period as classified by API. Furthermore, for the purpose of estimating daily mean soil temperature and cumulative evaporation on bare soil using only routine meteorological data, we propose that the surface moisture availability can be parameterized using the ratio of precipitation to potential evaporation with estimation periods ranging from 10 days to several months.
\end{abstract}

Key words: Bare soil, Evaporation, Parameterization, Soil temperature, Surface moisture availability.

\section{Introduction}

Evaporation from the soil surface is an important factor for energy and water balance over land surfaces. Surface moisture availability is the most important parameter for either estimating evaporation from bare soil using the bulk transfer method or for estimating soil temperature using the combined heat balance equation at the ground surface and the bulk transfer method (e.g., Kondo, 1994). A method for estimating

Received; March 23, 2009

Accepted; August 13, 2009. evaporation using the bulk transfer formula is expressed as the following:

$$
E=\rho \beta C_{H} U\left(q_{s a t}(T(0, t))-q_{a}\right)
$$

where $E$ is the evaporation $\left(\mathrm{mm} \mathrm{s}^{-1}\right), C_{H}$ is the bulk transfer coefficient for sensible heat flux (dimensionless number), $U$ is the wind speed $\left(\mathrm{m} \mathrm{s}^{-1}\right), C_{H} U$ is the exchange speed for sensible heat flux $\left(\mathrm{m} \mathrm{s}^{-1}\right), q_{a}$ is the specific humidity of the air $\left(\mathrm{kg} \mathrm{kg}^{-1}\right), q_{s a t}(T(0, t))$ is the saturation specific humidity at the ground surface temperature $\left(\mathrm{kg} \mathrm{kg}^{-1}\right)$ and time $t, \rho$ is the air density 
$\left(\mathrm{kg} \mathrm{m}^{-3}\right)$, and $\beta$ is the surface moisture availability, which ranges from 0 to 1 . Equation (1) is called the $\beta$ method.

Modeling evaporation by the bulk transfer method has the advantage of a simple equation form; it is direct and makes use of routine meteorological data easily measured in situ or remotely sensed data to calculate the potential evaporation (when $\beta=1$ ). According to Kondo et al. (1990), Mahfouf and Noihan (1991) and Lee and Pielke (1992), evaporation from bare soil strongly depends on surface soil moisture content. Therefore, $\beta$ is usually treated as a function of the volumetric water content of the upper few centimeters. Ye and Pielke (1993) proposed the parameterization formula for $\beta$ using not only surface soil moisture content but also more detailed soil physical conditions.

However, the bulk transfer method has some disadvantages. Experimental estimation of $\beta$ from Eq. (1) under in-situ field conditions for calibration or verification of $\beta$ usually requires the observed latent heat flux or evaporation, ground surface temperature and exchange speed $C_{H} U$ (or bulk transfer coefficient $C_{H}$ and wind speed $U$ ), in addition to routine meteorological data. Therefore, the bulk transfer method requires detailed, site-specific measurements or the inclusion of sensible and latent heat flux for the initial parameterization or verification of $\beta$. The bulk transfer method thus requires expensive instrumentation along with that of data logging capability and, as such, is limited to only well-monitored research locations. In addition, even if $\beta$ can be parameterized using surface soil moisture content, it is seldom monitored on a routine basis as with other atmospheric variables. Before the bulk transfer method can be used as a practical tool in various disciplines such as hydrology, climatology or agronomy, the method for determining surface moisture availability $\beta$ needs to be greatly simplified.

Studies have been conducted on estimating surface moisture availability $\beta$ from routine meteorological data (air temperature, solar radiation, precipitation, wind speed and humidity) and ground surface temperature without using flux observation data. For example, Kimura and Shimizu (1994) developed a linear heat budget model to estimate diurnal variation in latent and sensible heat flux and surface moisture availability on bare soil from the diurnal variation in the ground surface temperature and downward radiation, when the bulk transfer coefficient for sensible heat is given.
Matsushima and Kondo (1995) developed a linear heat budget model to simultaneously estimate daytime means of bulk transfer coefficient for sensible heat and surface moisture availability on bare soil using the daily variation in routine meteorological data and ground surface temperature. Furthermore, there is renewed interest in applying surface moisture availability to data assimilation for soil moisture through the surface heat budget model and ground surface temperature observation including the vegetation layer (Mahfouf, 1991; Lakshmi, 2000). Casteli et al. (1999) developed a robust method with respect to noise errors that is based on the methods developed by Mahfouf (1991) and $\mathrm{Hu}$ and Islam (1995). The objective of these studies was to estimate daily surface moisture availability and diurnal variation in latent and sensible heat flux. At this time scale, the accuracy of ground surface temperature is crucial; a systematic error of only $\pm 1^{\circ} \mathrm{C}$ in ground surface temperature can lead to erroneous estimates of these variables (Matsushima and Kondo, 1995). In practice, precise ground surface temperature estimation is difficult to achieve and is generally far from within $\pm 1^{\circ} \mathrm{C}$ from the satellite data (Lakshmi and Susskind, 2000).

Hirota et al. (1995) proposed a method for estimating cumulative evaporation and surface moisture availability $\beta$ from 10 days to several tens of days using routine meteorological data and daily mean soil temperature. They also suggested that the surface moisture availability $\beta$ may be parameterized using routine meteorological data such as precipitation without needing soil moisture values for the purpose of estimating cumulative evaporation and daily mean soil temperature. Their method offers the possibility of avoiding the problem of flux measurement, the difficulty of obtaining accurate ground surface temperature estimation and the need to use soil moisture data even though this application is limited to a longer time scale (more than 10 days, seasonal, annual or inter-annual).

We begin with a brief introduction of the method developed by Hirota et al. (1995) for estimating cumulative evaporation and averaged surface moisture availability value for a period ranging from 10 days to several tens of days using routine meteorological data and daily soil temperature values. Next, we explain how we improved our method in order to more efficiently estimate the averaged surface moisture availability. Lastly, we introduce the parameterization method for 
surface moisture availability $\beta$ without using soil moisture. The significance of this is that once we establish the parameterization for $\beta$, cumulative evaporation on bare soil for a long period (more than 10 days) can be estimated from routine meteorological data (air temperature, solar radiation, precipitation, wind speed and humidity) through the heat balance equation at the ground surface. Daily mean soil temperature can also be estimated, meaning that cumulative evaporation can be estimated without needing soil temperature after establishing parameterization of $\beta$. The estimation of daily mean soil temperature is also an especially useful and important factor for agriculture.

\section{Overview of previous work in Hirota et al. (1995) and Hirota and Fukumoto (1996)}

A method for estimating evaporation using a modified force-restore model (mFRM) for estimating daily mean soil temperature was developed by Hirota et al. (1995) from the original model by Bhumralkar (1975) (see Appendix for complete details). The modified version is for bare soil and uses routine meteorological data and daily soil temperature values (a few $\mathrm{cm}$ to a few tens of $\mathrm{cm}$ order). It is not always necessary to use the observed ground surface temperature (surface skin temperature or depth of a few mm order). This feature is an advantage because an accurate ground surface temperature is not easy to observe (Bittelli et al. 2008), as a large temperature gradient often exists near the surface in dry soil conditions (Saigusa et al. 1993) and it is also difficult to accurately estimate within $\pm 1^{\circ} \mathrm{C}$ from the satellite data. The study, reported by Hirota et al. (1995), showed that if the daily mean soil temperature can be accurately simulated, then the cumulative evaporation can also be simulated, without the measurement of latent and sensible heat flux. Also, the surface moisture availability value $\beta$ could remain constant for periods of 10 days or longer according to weather conditions (especially precipitation amount or soil wetness condition), meaning that the daily value of $\beta$, or that of measured soil moisture, is not needed.

The study also showed that although the effects of thermometric parameters (soil heat capacity $c$, damping depth $D_{a}$ ) on the calculation of diurnal variation in soil temperature are sensitive, those on the calculation of daily mean soil temperature or cumulative evaporation are relatively insensitive. Therefore, the determining of soil thermometric parameters does not need detailed parameter characteristics such as dependency on soil moisture. These soil parameters can be treated as a constant value under each soil type. Also, if mFRM is used, the soil thickness ranges from several $\mathrm{cm}$ to several tens of $\mathrm{cm}$, and hence it is not necessary to know the soil thermometric parameters of the deep layer.

The exchange speed $C_{H} U$ can be estimated from the roughness length for momentum, roughness length for sensible heat, zero plane displacement, wind speed measurement, and universal function of the stability parameter (or Richardson number). However, the roughness length for sensible heat is not always easy to correctly estimate because the value is affected by the scale of fetch even under the same surface conditions (e.g., Kondo, 1994). Hirota and Fukumoto (1996) showed that the exchange speed for sensible heat $C_{H} U$ on bare soil can be estimated by using routine meteorological data without using observed sensible heat flux. If the soil surface is sufficiently wet after a day of precipitation, assuming that $\beta=1$ and daily mean soil heat flux is negligible, then $C_{H} U$ can be calculated by the following equation:

$$
C_{H} U=\frac{(1-a) R_{s}+\varepsilon\left\{L_{d}-\sigma\left(273.15+T_{s}\right)^{4}\right\}}{\operatorname{cp} \rho\left\{T(0, t)-T_{a}\right\}+l \rho\left\{q_{s a t}\left(T_{s}\right)-q_{a}\right\}}
$$

where $R_{s}$ is the solar radiation $\left(\mathrm{W} \mathrm{m}^{-2}\right), L_{d}$ is the atmospheric long wave radiation $\left(\mathrm{W} \mathrm{m}^{-2}\right), a$ is the albedo of soil surface, $\varepsilon$ is the emissivity of the ground, $\sigma$ is the Stefan-Boltzmann constant $\left(\mathrm{W} \mathrm{m}^{-2} \mathrm{~K}^{-4}\right), l$ is the heat of vaporization $\left(\mathrm{J} \mathrm{kg}^{-1}\right), q_{a}$ is the specific humidity of the air $\left(\mathrm{kg} \mathrm{kg}^{-1}\right), q_{\text {sat }}(T S)$ is the saturation value of the specific humidity $\left(\mathrm{kg} \mathrm{kg}^{-1}\right)$ at the ground surface temperature and $T_{s}$ is the daily mean ground surface temperature $\left({ }^{\circ} \mathrm{C}\right)$. In this case, $T_{s}$ can be the soil temperature at the $1-2 \mathrm{~cm}$ depth. The reason is that the temperature gradient of the daily mean value is not large in wet condition, then the ground surface temperature is not sensitively dependent on the soil depth for daily mean values under wet conditions (Hirota and Fukumoto, 1996).

Therefore, the method of Hirota et al. (1995) is valid for the heat balance at the ground surface because it provides reasonable $C_{H} U$. The two previous studies (Hirota et al. 1995; Hirota and Fukumoto, 1996) suggest that the surface moisture availability $\beta$ can be easily estimated using only routine meteorological data without needing observed latent and sensible heat flux data. This is possible as other required 
parameters (exchange speed for sensible heat flux, soil thermometric parameters) can be easily determined from the previous paragraphs in this section. At least a 10-day period is necessary for estimation of $\beta$ because without the measurement of soil moisture, precipitation conditions are needed. Here, we concretely show the parameterization of surface moisture availability $\beta$ over a long period (more than 10 days) without using soil moisture. In addition, before estimating $\beta$ over a long period (more than 10 days), a proper calculation period should be determined using soil moisture status without using soil moisture. In the method of Hirota et al. (1995), the calculation period was determined through trial and error by comparing the observed soil temperature and estimated soil temperature. However, in this case, the calculation procedure is comparatively complex and a more efficient procedure is desirable. If the proper calculation period can be determined without using the trial and error method, the procedure for estimating $\beta$ would be easier. We also show how, in this study, the proper calculation period is efficiently determined according to soil moisture status but without using soil moisture.

\section{Data}

\section{Meteorological data}

The following daily data from the meteorological station at the National Agricultural Research Center for Hokkaido Region $\left(43.0^{\circ} \mathrm{N}, 141.4^{\circ} \mathrm{E}\right)$ (Sameshima et al., 2008) was used for the estimation of $l E$ and $\beta$ in this study.

(1) Solar radiation $R_{s}\left(\mathrm{~W} \mathrm{~m}^{-2}\right)$

(2) Sunshine duration $N(\mathrm{~h})$

(3) Mean air temperature $T_{a}\left({ }^{\circ} \mathrm{C}\right)$

(4) Mean wind speed $U_{10}\left(\mathrm{~m} \mathrm{~s}^{-1}\right)$ at $10 \mathrm{~m}$ height

(5) Mean specific humidity $q_{a}\left(\mathrm{~kg} \mathrm{~kg}^{-1}\right)$

(6) Amount of precipitation $\operatorname{Pr}(\mathrm{mm})$

(7) Mean soil temperature $T_{g}\left({ }^{\circ} \mathrm{C}\right)$ at a depth of 0.05 $\mathrm{m}$ in bare soil (volcanic ash soil)

\subsection{Parameters}

Parameters required to estimate the surface moisture availability over a long period using the proposed method are shown in Table 1. Parameters $c, D_{a}, C_{H} U$, and $a$ were determined based on field and laboratory experiments and were adopted from the averaged value (Fukumoto and Hirota, 1994; Hirota et al., 1995; Hirota and Fukumoto, 1996). The emissivity of ground $\varepsilon$ is assumed to be unity in this study.

\subsection{Surface soil moisture data}

Volumetric soil moisture content $\left(\mathrm{m}^{3} \mathrm{~m}^{-3}\right)$ in the 0-0.02 $\mathrm{m}$ layer of bare soil was measured by the gravimetric method every day at 09:00 to analyze the soil wetness condition. The observation period was from May 15, 1992 to August 14, 1992 (Fukumoto and Hirota, 1994).

\section{Method for estimating $\beta$}

\subsection{Estimation of soil wetness condition}

The antecedent precipitation index $(A P I)$ is frequently used for qualitative judgment of the soil wetness condition (Saxton and Lenz, 1967; Iwai and Ishiguro, 1977; Wang, 1985; Choudhury and Blanchard, 1983; Kondo et al. 1998; Shinoda et al. 2000). Although there are many types of API expressions, the one used in our paper is given by the following equation (Choudhury and Blanchard, 1983):

$$
A P I_{j}=K_{j}\left(A P I_{j-l}+P r_{j}\right)
$$

where $A P I_{j}$ is the antecedent precipitation index on Day $j, P r_{j}$ is the amount of precipitation (mm) on Day $j$, and $K_{j}$ is the recession coefficient defined by

$$
K_{j}=\exp \left(-E p_{j} / W_{m}\right)
$$

where $E p_{j}$ is the daily potential evaporation $(\mathrm{mm})$ on Day $j$ and $W_{m}$ is the maximum depth of soil available for evaporation $(\mathrm{mm})$. The potential evaporation $E p_{j}$ can be calculated from Eqs. (10) to (20) (Appendix) in the case of $\beta=1$ and ground soil heat flux $G=0$.

Table 1. Values of parameters used in this study.

\begin{tabular}{lcl}
\hline \multicolumn{1}{c}{ Item } & Symbol & \multicolumn{1}{c}{ Value } \\
\hline Volumetric heat capacity & $c\left(\mathrm{~J} \mathrm{~m}^{-3} \mathrm{~K}^{-1}\right)$ & $2.0 \times 10^{6}$ \\
Damping depth & $D_{a}(\mathrm{~m})$ & 1.7 \\
Exchange speed & $C_{H} U$ & $0.00229 \times 0.7 U_{10}+0.00456$ \\
Annual mean soil temperature & $T_{y m}\left({ }^{\circ} \mathrm{C}\right)$ & 9.0 \\
Surface emissivity & $\varepsilon$ & 1.00 \\
Soil albedo & $a$ & 0.1 (rainy day) \\
& & 0.25 (other days) \\
\hline
\end{tabular}




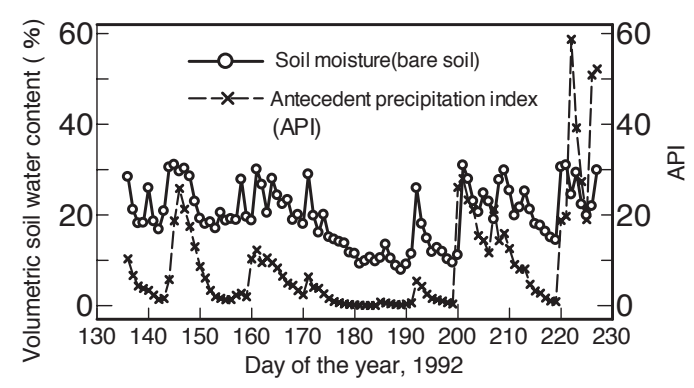

Fig. 1. Temporal variations in soil moisture at 0-0.02 m layer and antecedent precipitation index $(A P I)$.

Fig. 1 shows the relationship between $A P I$, in the case of $W_{m}=10$, and soil moisture in the $0-0.02 \mathrm{~m}$ soil layer. The variation in $A P I$ is similar to that in soil moisture. As such, the $A P I$ is useful for classifying the soil wetness condition in estimating the average value of $\beta$ over a long period. In this calculation, an $A P I$ value $\geq 20$ corresponds to soil moisture content equivalent to or greater than field capacity. When the $A P I$ value remains continuously $<1$, this is regarded as the dry condition, and may correspond to the third stage of evaporation processes over bare soil ( $\mathrm{He}$ and Kobayashi, 1998; Kobayashi et al. 1999). From this analysis of the relationship between soil moisture variation and $A P I$, we classified soil wetness into the following three conditions so as to estimate $\beta$ :

1: Wet condition (greater than or equivalent to field capacity when $A P I \geq 20$ );

2: Semi-dry condition $(20>A P I \geq 1)$ for more than 10 consecutive days; and

3: Dry condition $(A P I<1)$ for more than 10 consecutive days.

If $A P I \geq 20$ does not occur for more than 10 consecutive days, the soil condition is classified as semi-dry. Also, if the dry condition $(A P I<1)$ does not occur for more than 10 consecutive days, the soil condition is classified as semi-dry.

It is considered that $W_{m}$ is a complex function of soil physical and plant properties (Choudhury et al. 1987) and therefore, it is not easy to determine this value in practice. If $W_{m}$ is changed, the classification value of $A P I$ is also changed.In this case, we assumed that $W_{m}=10$. If $W_{m}=20$, the wet condition is defined as $A P I$ $\geq 30$, the semi-dry condition is defined as $30>A P I \geq$ 5 , and the dry condition is defined as $A P I<5$. If $W_{m}$ is three times the value $\left(W_{m}=30\right)$, the wet condition is defined as $A P I \geq 35$, the semi-dry condition is defined as $35>A P I \geq 10$ and the dry condition is defined as $A P I<10$. However, the pattern of variation is the same, as long as $W_{m}$ is taken as a constant throughout the study period, and it is still easy to roughly classify the soil wetness condition using $A P I$. In this study, $A P I$ is used to classify the state of soil wetness on bare soil as a qualitative and auxiliary method for determining the calculation period for $\beta$ over periods ranging from 10 days to several months; it is not used to correctly estimate daily soil moisture values. For the purpose of qualitative judgment of soil wetness condition, we assumed that it is not important to correctly obtain $W_{m}$.

\subsection{Estimation and parameterization of $\beta$}

The mFRM (see Appendix) for estimating daily mean soil temperature can be solved to estimate surface moisture availability $\beta$, latent heat flux $l E$, and sensible heat flux $H$ for given meteorological, soil, and surface roughness conditions (Hirota et al. 1995; Hirota, 1999) via the procedures summarized in Fig. 2 and detailed in the following paragraphs.

First, the soil wetness condition is classified using $A P I$. Second, the exchange speed $C_{H} U$ is estimated using Eq. (2) for wet conditions $(A P I \geq 20)$ and $C_{H} U$ is parameterized as a linear function of daily mean wind speed (Hirota and Fukumoto, 1996). Third, the surface moisture availability $\beta$ is estimated for the daily mean meteorological data and the given soil parameter using the mFRM (Appendix) under given proper estimation period based on the soil wetness condition. The procedure for estimating the surface moisture availability $\beta$ is as follows. Choose $\beta$ to minimize the sum of the squares of the residual between the observed value of the daily mean soil temperature and the calculated value, $\chi^{2}$, written as

$$
\chi^{2}=\Sigma\left\{T_{\delta}(\text { calculated })-T_{\delta}(\text { observed })\right\}^{2}
$$

Here, the summation should be taken over the proper estimation period. The proper estimation period was determined by using API information. It should be noted that the recommended calculation period for $\beta$ is at least 10 days. The proper estimation period $\beta$ is basically taken from the first occurrence of $A P I \geq 20$ to the next period just before $A P I \geq 20$. Furthermore, for the case of estimating $\beta$ more accurately under dry condition, the period $\beta$ is taken from the first timing of dry conditions $A P I<1$ to the next timing just before $A P I \geq 20$. If the period between two 


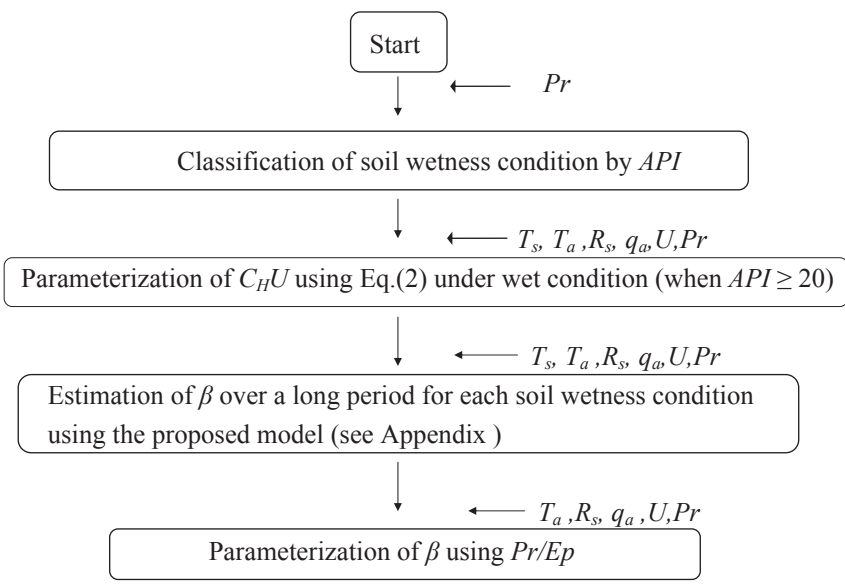

Fig. 2. Procedure for parameterization of the surface moisture availability $\beta$ without flux measurement and soil moisture.

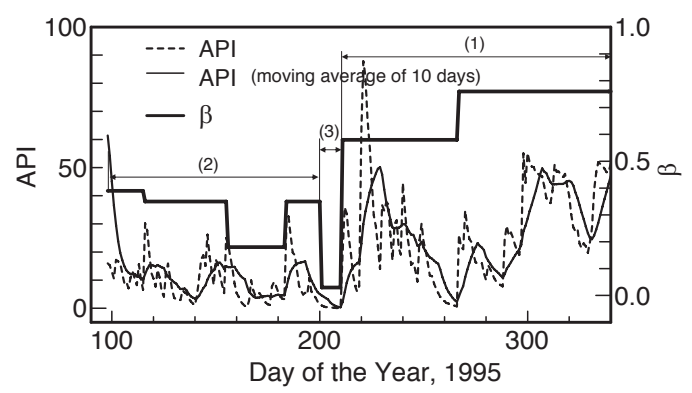

Fig. 3. The soil moisture availability $\beta$ and the API. (1) wet condition period, (2)semi-dry condition period,(3) dry condition period.

consecutive occurrences of $A P I \geq 20$ is not more than 10 consecutive days, the soil wetness condition is classified as a semi-dry condition. Also, if $A P I<1$ is not more than 10 consecutive days, the soil wetness condition is classified as a semi-dry condition. Thus, $A P I$ is used to determine the calculation (averaging) period for estimating $\beta$ (see the example in Fig. 3). This procedure using API is helpful for achieving correct and efficient estimation of $\beta$. From these procedures, we can estimate surface moisture availability on bare soil without using observed sensible and latent flux.

In the fourth and final step, we introduce the parameterization method for surface moisture availability $\beta$ without using soil moisture. $\beta$ is parameterized using the ratio of the precipitation $P r$ to potential evaporation $E p$, where $E p$ is calculated from Eqs. (10) to (20) (Appendix) in the case of $\beta=1$ and soil heat flux at the surface $G=0$. This method of parameterization is
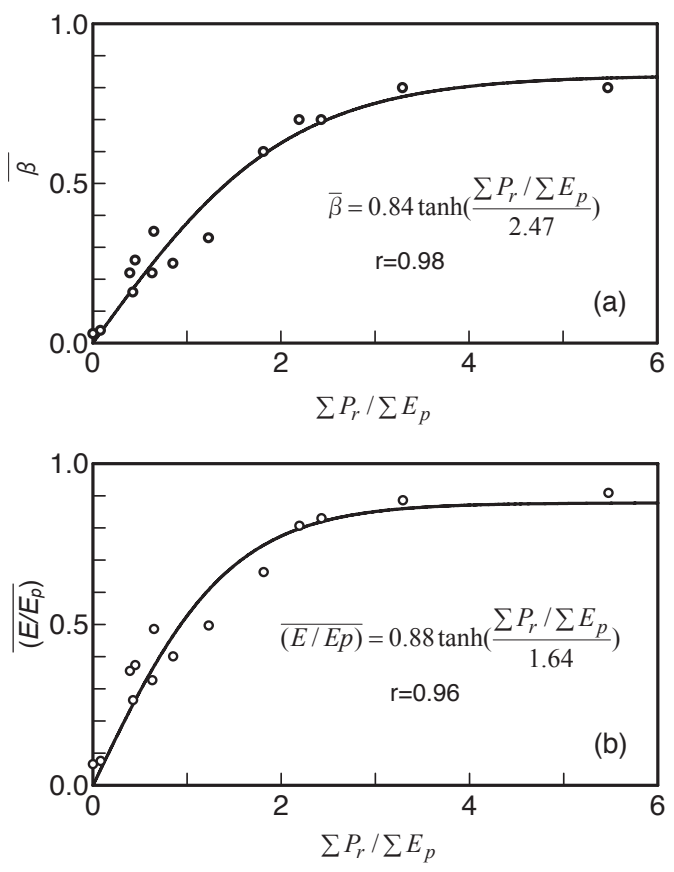

Fig. 4. Relationship between $\operatorname{Pr} / E p$ and $\beta$ (a); between $\operatorname{Pr} / E p$ and $E / E p(b)$.

often used for the annual mean period (e.g., Budyko, 1974; Kondo and Xu, 1997). In our study, we applied this parameterization to shorter periods ranging from 10 days to several months, which was based on soil wetness conditions determined by API. Fig. 4 shows the relationship between $\beta, E / E p$ and the mean value of Pr/Ep using data from 1992 to 1994 from spring to fall during conditions of no snow cover. Fitting equations 
describing the relationship between $\beta$ and $\operatorname{Pr} / E p$ and between $E / E p$ and $\operatorname{Pr} / E p$ are as follows:

$$
\begin{aligned}
& \bar{\beta}=0.84 \tanh \left(\frac{\left(\sum \operatorname{Pr} / \sum E p\right)}{2.47}\right), \text { for } \sum \operatorname{Pr} / \sum \mathrm{Ep} \\
& >0, \text { where for } \sum \operatorname{Pr} / \sum \mathrm{Ep}=0, \beta=0.03
\end{aligned}
$$

$$
\begin{aligned}
& \overline{(E / E p)}=0.88 \tanh \left(\frac{\sum P r / \sum E p}{1.64}\right), \text { for } \sum \operatorname{Pr} / \sum E p \\
& >0, \text { where for } \sum \operatorname{Pr} / \sum E p=0, \overline{(E / E p)}=0.07
\end{aligned}
$$

where, $\bar{\beta}$ and $\overline{(E / E p)}$ are each average value during the calculation period based on soil wetness conditions determined by $A P I$. $\sum P r$ and $\Sigma E p$ are each summation value during the calculation period based on soil wetness conditions determined by $A P I$.

These results show that $\bar{\beta}$ or $\overline{(E / E p)}$, for periods of more than 10 days, can be parameterized without using soil moisture. We already showed that this method can be used to correctly estimate cumulative evaporation on bare soil for a long period (more than 10 days) with evidence that supports the heat balance since a valid exchange speed $C_{H} U$ is given (Hirota et al. 1995).

\section{Verification results}

Once we establish the parameterization for $C_{H} U$ and $\beta$, the daily mean soil temperature and cumulative evaporation can be estimated using routine meteorological data (e.g., air temperature, humidity, solar radiation, sunshine duration, wind speed, and precipitation). In the previous section, we established the relationship between $\beta$ and $\operatorname{Pr} / E p$ using 1992-1994 data. In this section, in order to verify the parameterization result for $\beta$ in Fig. 4 (Eq. 6), the rest of the dataset, 19951997, was used.

Fig. 5 shows the schematic diagram for estimating daily mean soil temperature and evaporation by using the mFRM (see Appendix). In this procedure, the API also has an important role as it is used to determine the calculation period (averaging period) for estimating $\beta$ for each soil moisture status. After determining the calculation period, $\operatorname{Pr} / E p$ is calculated for each period, and then $\beta$ is estimated using Eq. 6 (Fig. 4). An example of the variation in $A P I\left(W_{m}=10\right)$ and the results for estimating $\beta$ using Eq. 6 are shown in Fig. 3.

Thus, since $\beta$ can be obtained, the daily mean soil temperature and other heat balance components can be

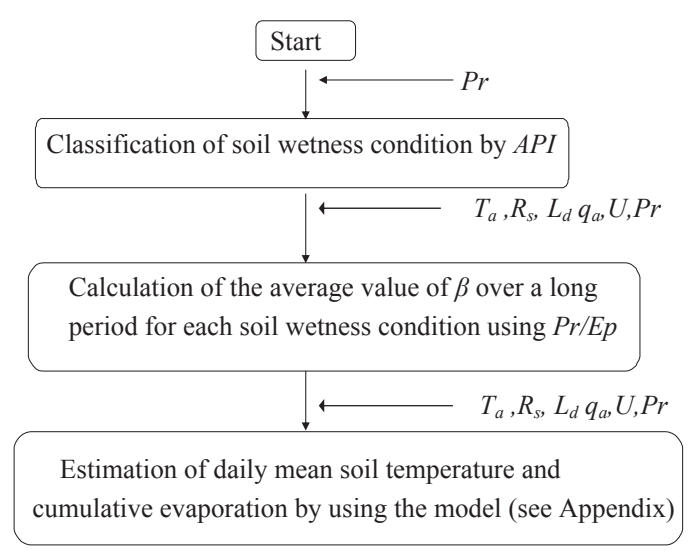

Fig. 5. Procedure for estimating surface moisture availability, daily mean soil temperature and cumulative evaporation.

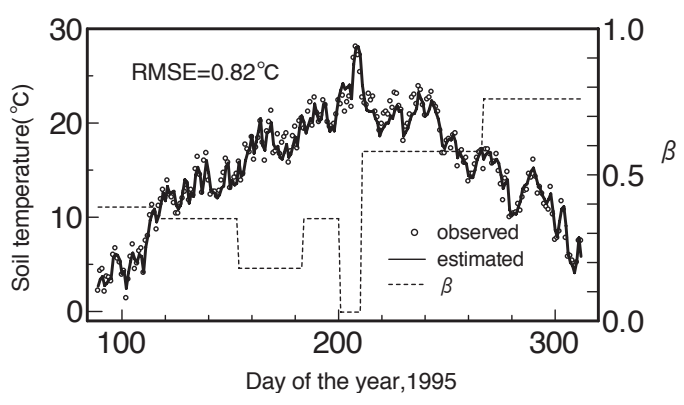

Fig. 6. Comparison of daily mean soil temperature at a depth of $0.05 \mathrm{~m}$ and estimated surface moisture availability $\beta$ (1995 year).

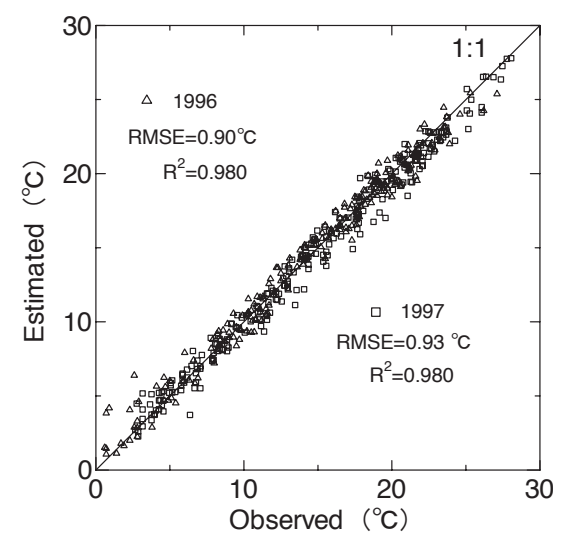

Fig. 7. Comparison of daily mean soil temperature at a depth of $0.05 \mathrm{~m}$ (1996 and 1997 year).

estimated using the procedure in Fig. 5. Fig. 6 and 7 show the comparison of observed soil temperature and 
that estimated by the procedure shown in Fig. 5 for the years 1995 through to 1997 . The temporal variation in estimated values of daily mean soil temperature corresponds well with the observed values during 1995, 1996 and 1997. The root mean square error (RMSE) of the annual period varied between $0.82^{\circ} \mathrm{C}$ and $0.93^{\circ} \mathrm{C}$ during 1995 to 1997 . On the other hand, the case when $\beta$ is treated as a constant value over the calculation period, the RMSE in $1995(\beta=0.35)$ was $0.91^{\circ} \mathrm{C}$, that in $1996(\beta=0.30)$ was $1.10^{\circ} \mathrm{C}$ and that in $1997(\beta=$ 0.18 ) was $1.06^{\circ} \mathrm{C}$. The accuracy was improved by 0.1 to $0.2^{\circ} \mathrm{C}$ by using the calculation period determined by API. These results show that the daily mean soil temperature can be reasonably estimated using our proposed method for $\beta$.

\section{Discussion and Conclusions}

We developed a simple method for estimation and parameterization of surface moisture availability over periods ranging from 10 days to several months on bare soil using only routine meteorological data without needing sensible and latent heat flux and soil moisture data. The data required for our method is daily mean soil temperature, daily mean air temperature, daily solar radiation, sunshine duration, daily precipitation, daily mean wind speed, and daily mean humidity. The surface moisture availability can be estimated by using a simple soil temperature model composed of the heat balance equation at the ground surface, bulk transfer method and modified force-restore model. The estimation period of surface moisture availability can range from 10 days to several months in duration. We showed that the antecedent precipitation index $(A P I)$ was an effective indicator for judging the soil wetness condition and thus for classifying the proper estimation period of surface moisture availability. Furthermore, for the purpose of estimating daily mean soil temperature and cumulative evaporation on bare soil using only routine meteorological data, we show that the surface moisture availability can be parameterized using the ratio of precipitation to potential evaporation based on soil wetness conditions classified using the API method. This parameterization does not require soil moisture data.

In this study, we used an empirical method to judge the soil wetness condition. As there are many other API methods, further research may be needed to find a more suitable one. Our proposed method cannot be used for shorter time scales such as a diurnal cycle. This is a disadvantage compared with previous parameterization methods for surface moisture availability based on surface soil moisture content (e.g., Kondo et al. 1990; Lee and Pielke, 1992; Mahfouf and Noilhan 1991; Fukumoto and Hirota, 1994). However, our method has the advantage of needing only routine metrological data without needing special measurements. Also, by using daily mean values, the estimated value cancels out the error of each hourly estimation (Hirota et al. 1995; Hirota et al. 2001) and the effect of soil thermal properties on the calculation of annual variations in the mean daily soil surface temperature is small, compared to the effect on diurnal variations (Hirota et al. 1995; Hirota et al. 2002). Therefore, this method can reduce the effect of observation error on the estimated value.

Although verification in this study is limited to only bare soil and relatively humid conditions, we consider that application of our parameterization method can be expanded to drier and vegetation fields. The function form of $\operatorname{Pr} / E p$ is similar to the radiative index of dryness proposed by Budyko (1974), which can be applied to not only bare soil but any vegetation and climatic region for estimating regional and annual evaporation (Gutman et al. 1984). In this study, we show that the function of $\mathrm{Pr} / \mathrm{Ep}$ could be applied to a shorter time scale ranging from 10 days to several months on bare soil by using API for classifying soil moisture status. Future work using the method in this study can be expanded to vegetation fields by combining the functions of $\operatorname{Pr} / E p$ and $A P I$. In order to expand our method for vegetation areas, using remote sensing data such as surface temperature and normalized differential vegetation index (NDVI) may be more effective than the use of soil temperature for bare soil.

\section{APPENDIX}

Modified version of force-restore model for estimating daily mean soil temperature (Hirota $e t$ al. 1995; Hirota, 1999)

The modified version of the force-restore model for estimating daily mean soil temperature using daily mean or daily meteorological data is expressed by 


$$
\begin{aligned}
& C 1(\delta) \frac{\partial T_{g}(\delta, t)}{\partial t} \\
& =\frac{2}{c D_{a}} G(0, t)-\frac{2 \pi}{\tau_{y}}\left(T_{g}(\delta, t)-T_{y m}\right)
\end{aligned}
$$

where $T_{g}(\delta, t)$ is the average temperature $\left({ }^{\circ} \mathrm{C}\right)$ in a soil layer with a thickness of $\delta(\mathrm{m})$, defined as,

$$
T_{g}(\delta, t)=\frac{1}{\delta} \int_{0}^{\delta} T(z, t) d z
$$

$T(z, t)$ is the soil temperature over some vertical depth, $z$, and time $t, c$ is the volumetric heat capacity of soil $\left(\mathrm{J} \mathrm{m}^{-3} \mathrm{~K}^{-1}\right), D_{a}$ is the damping depth for annual value $(\mathrm{m}), G(0, t)$ is the soil heat flux at the surface $\left(\mathrm{W} \mathrm{m}{ }^{-2}\right), T_{y m}$ is the annual mean soil temperature $\left({ }^{\circ} \mathrm{C}\right), \tau_{y}$ is the annual period (365 days), and. $C 1(\delta)=$ $\left(1+2 \delta / D_{a}\right) . T_{y m}$ is relatively invariant with depth until a depth of several meters (Hirota et al. 1995; Hirota et al. 2002), therefore $T_{y m}$ can be adopted for any depth up to several meters.

The force-restore model (FRM) was originally developed for the simple prediction of diurnal variation in ground surface temperature (Bhumralkar, 1975). Regarding the annual variation in the daily mean value, we have shown that the force-restore model not only accurately estimates ground surface temperature but also soil temperature in a layer up to approximately $0.5 \mathrm{~m}$ thick for agricultural land (Hirota et al. 1995; Hirota, 1999).

Equation (8) is used in combination with the following Eqs. (10) to (20).

In the case of $\delta \rightarrow 0$

$$
\frac{\partial T_{g}(0, t)}{\partial t}=\frac{2}{c D_{a}} G(0, t)-\frac{2 \pi}{\tau_{y}}\left(T_{g}(0, t)-T_{y m}\right)
$$

where $T_{g}(0, t)$ is the ground surface temperature $\left({ }^{\circ} \mathrm{C}\right)$. The heat balance at the ground surface is given by:

$$
\begin{gathered}
G(0, t)=R_{n}-l E-H \\
R_{n}=(1-a) R_{s}+\varepsilon\left(L_{d}-\sigma(273.15+T(0, t))^{4}\right)
\end{gathered}
$$

where $R_{n}$ is the net radiation ( $\mathrm{W} \mathrm{m}^{-2}$ ), $R_{s}$ is the solar radiation $\left(\mathrm{W} \mathrm{m}^{-2}\right), L_{d}$ is the atmospheric long-wave radiation $\left(\mathrm{W} \mathrm{m}^{-2}\right), l E$ is the latent heat flux $\left(\mathrm{W} \mathrm{m}^{-2}\right)$, $H$ is the sensible heat flux $\left(\mathrm{W} \mathrm{m}^{-2}\right), a$ is the soil albedo, $\varepsilon$ is the emissivity of the ground, and $\sigma$ is the
Stefan-Boltzmann constant $\left(\mathrm{W} \mathrm{m}^{-2} \mathrm{~K}^{-4}\right)$. The latent heat flux $l E$ and the sensible heat flux $H$ are expressed by the following bulk formula (Kondo, 1994):

$$
\begin{aligned}
& H=c_{p} \rho C_{H} U\left(T(0, t)-T_{a}\right) \\
& l E=l \rho \beta C_{H} U\left(q_{s a t}(T(0, t))-q_{a}\right)
\end{aligned}
$$

where $l$ is the latent heat of vaporization $\left(\mathrm{J} \mathrm{kg}^{-1}\right), \beta$ is the surface moisture availability, $C_{H}$ is the bulk transfer coefficient for sensible heat flux, $U$ is the wind speed $\left(\mathrm{m} \mathrm{s}^{-1}\right), C_{H} U$ is the exchange speed for sensible heat flux $\left(\mathrm{m} \mathrm{s}^{-1}\right), q_{a}$ is the specific humidity of the air $(\mathrm{kg}$ $\left.\mathrm{kg}^{-1}\right), q_{\text {sat }}\left(T_{g}(0, t)\right)$ is the saturation value at the ground surface temperature $\left(\mathrm{kg} \mathrm{kg}^{-1}\right), c_{p}$ is the specific heat of the air $\left(\mathrm{J} \mathrm{kg}^{-1} \mathrm{~K}^{-1}\right), \rho$ is the air density $\left(\mathrm{kg} \mathrm{m}^{-3}\right)$, and $T_{a}$ is the air temperature $\left({ }^{\circ} \mathrm{C}\right)$.

The daily mean atmospheric long-wave radiation $L_{d}$ is estimated by the following equations (Kondo, 1994):

$$
\begin{gathered}
L_{d}=C_{c} L_{d f}+\left(1-C_{c}\right) \sigma\left(273.15+T_{a}\right)^{4} \\
C_{c}=\mathrm{A}_{1}(n / N)^{3}-\mathrm{A}_{2}(n / N)^{2}+\mathrm{A}_{3}(n / N)+\mathrm{A}_{4}
\end{gathered}
$$

where $C_{c}$ is the cloudiness factor, $N$ is the possible sunshine duration and $n$ is the sunshine duration. Here, $\mathrm{A}_{1}=2.1, \mathrm{~A}_{2}=-3.241, \mathrm{~A}_{3}=2.291$, and $\mathrm{A}_{4}=0.291$, as coefficients obtained at the Hokkaido National Agricultural Research Center for Hokkaido Region from observed data in 1992 (Hirota et al. 1995).

$L_{d f}$ is the daily mean atmospheric long-wave radiation under clear sky conditions ( $\mathrm{W} \mathrm{m}^{-2}$ ) and is estimated from air temperature and effective water vapor amount using the following equations (Kondo, 1994):

$$
L_{d f}=\left(0.74+0.19 x+0.07 x^{2}\right) \sigma\left(273.15+T_{a}\right)^{4}
$$

$$
\begin{aligned}
& x=\log _{10} w_{T O P}^{*} \\
& \log _{10} w_{T O P}^{*}=0.0315 T_{D E W}-0.1836
\end{aligned}
$$

$$
T_{D E W}=\frac{237.3 \log _{10}\left(\frac{e_{a}}{6.11}\right)}{7.5-\log _{10}\left(\frac{e_{a}}{6.11}\right)}
$$

where $w_{T O P}^{*}$ is the effective water vapor amount $(\mathrm{cm})$, $T_{D E W}$ is the dew point temperature $\left({ }^{\circ} \mathrm{C}\right)$ and $e_{a}$ is the 
daily mean vapor pressure $(\mathrm{hPa})$.

The model was typically used to estimate daily mean ground surface temperature or daily mean soil temperature in a layer with a thickness of $\delta$. From our soil temperature observation value, we found that $T_{g}(\delta, t) \approx T(\delta / 2, t)$ within $0.4 \mathrm{~m}$ thickness (Hirota et al. 1995). Therefore, in this model verification study, model output value $T_{g}(0.1, t)$ was compared with observed $T(0.05, t)$.

\section{Acknowledgements}

We thank Charles Maule for editing the first draft. The study was partially funded by the Global Environment Research Fund (Ba-087) from the Ministry of the Environment, Japan. Comments by the anonymous reviewers improved the manuscript.

\section{References}

Bhumralkar, C. M., 1975: Numerical experiment on the computation of ground surface temperature in an atmospheric circulation model. J. Appl. Meteorl., 14, 246-1258.

Bittelli, M., Ventura, F., Campbell, G. S., Snyder, R. L., Gallegati, F., and Pisa, P. R., 2008: Coupling of heat, water vapor, and liquid water fluxes to compute evaporation in bare soils. J. Hydrol. 362, 191-205.

Budyko, M. I., 1974: Climate and Life. Academic Press, 508pp.

Casteli, F., Entekhabi, D., and Caporali, E., 1999: Estimation of surface heat flux and an index of soil moisture using adjoint-state surface energy balance. Water Resour. Res., 35, 3115-3125.

Choudhury, B. J., and Blanchard, B. J., 1983: Simulating soil water recession coefficients for agricultural watersheds. Water Res. Bull., 19, 241-247.

Choudhury, B. J., Owe, M., Goward, S. N., Golos, R. E., Ormsby, J. P., Chang, A. T. C., and Wang, J. R., 1987: Quantifying spatial and temporal variabilities of microwave brightness temperature over the U.

S. Southern Great plains. Int. J. Remote. Sensing, 8, 177-191.

Fukumoto, M., and Hirota, T., 1994: The effect of surface soil moisture on a heat balance at a bare soil surface. J. Jpn. Soc. Hydro. Water Resour., 7, 393-401 (in Japanese with English summary).

Gutman, G., Ohring, G., and Joseph, J. H., 1984: Interaction between the geobotanic state and climate: A suggested approach and a test with a zonal model. J. Atmos. Sci., 41, 2663-2678.
He, W., and Kobayashi, T., 1998: A rational parameterization of evaporation from dry, bare soil. $J$. Meteorol. Soc. Jpn., 76, 955-963.

Hirota, T., 1999: Studies on evaluation of soil temperature, soil moisture and heat balance at the earth's surface for long periods under farmland and natural field conditions. Res. Bull. Hokkaido Natl. Agric. Exp. Stn., 169, 87-145 (in Japanese with English summary).

Hirota, T., and Fukumoto, M., 1996: A discussion of ground surface temperature on a bare soil surface and an estimation of the daily mean value of sensible heat flux using routine meteorological data. J. Jpn. Soc. Hydrol. Water Resour., 9, 395-403 (in Japanese with English summary).

Hirota, T., Fukumoto, M., Shirooka, R., and Muramatsu, K., 1995: Simple method of estimating daily mean soil temperature by using Force-Restore Model. J. Agric. Meteorol., 51, 269-277 (in Japanese with English abstract).

Hirota, T., Fukumoto, M., Shirooka, R., and Yamada, K., 2001: Estimation of the cumulative sensible heat flux and its daily mean soil temperature on a bare soil without wind speed data. J. Jpn. Soc. Hydrol. Water Resour. Res., 14, 289-297.

Hirota, T., Pomeroy, J. W., Granger, R. J., and Maule, C. P., 2002: An extension of the force-restore method to estimating soil temperature at depth and evaluation for frozen soils under snow. J. Geophys. Res., 107(D24), 4767. DOI: 10. 1029/2001JD001280.

Hu, Z., and Isram, S., 1995: Prediction of ground surface temperature and soil moisture content by the force-restore method. Water Resour. Res., 31, 2531-2539.

Iwai, S., and Ishiguro, M., 1977: Applied hydro-statistics, Morikita Co. Ltd., 326-343 (in Japanese).

Kimura, F., and Shimizu, Y., 1994: Estimation of sensible and latent heat fluxes from soil surface temperature using a linear air-land heat transfer model. J. Appl. Meteorol., 33, 477-489.

Kobayashi, T., He, W., and Nagai, H., 1998: Mechanisms of evaporation from soil with a dry surface. Hydrol. Process., 12, 2185-2191.

Kondo, A., Higuchi, A., Kishi, S., Fukuzono, T., and Li, J., 1998: The use of multi-temporal NOAA/ACHRR data to monitor surface moisture status in the Huaihe River basin, China. Adv. Space Res., 22, 645-654.

Kondo, J., ed., 1994: Meteorology of the water environment. - Water and heat balance of the earth- 
Asakura Co. Ltd., 337pp (in Japanese).

Kondo, J., Saigusa, N., and Sato, T., 1990: A parameterization of evaporation from bare soil surface. $J$. Appl. Meteorol., 29, 385-389.

Kondo, J., and Xu, J., 1997: Seasonal variations in heat and water balances for non-vegetated surface. J. Appl. Meteorol., 36, 1676-1695.

Lakshmi, V., 2000: A simple surface temperature assimilation scheme for use in land surface models. Water Resour. Res., 36, 3687-3700.

Lakshmi, V., and Susskind, J., 2000: Comparison of TOVS-derived land surface variables with ground observations. J. Geophys. Res., 105, D2, 2179-2190.

Lee, T. J., and Pielke, R. A., 1992: Estimating the soil surface humidity. J. Appl Meteor., 31, 480-484.

Mahfouf, J., 1991: Analysis of soil moisture from near-surface parameters: A feasibility study. J. Appl. Meteorol., 30, 1534-1548.

Mahfouf, J., and Noilhan, J., 1991: Comparative study of various formulations of evaporation for bare soil using in situ data. J. Appl. Meteorol., 30, 1354-1365.

Matsushima, D., and Kondo, J., 1995: An estimation of the bulk transfer coefficients for a bare soil surface using a linear model. J. Appl. Meteorol., 34, 927-940.
Saigusa, N., Yamazaki, T., and Kato, K., 1993: Errors in land surface temperature measurements from stem thermometer. J. Jpn. Soc. Hydrol. Water Resour., 6, 12-16 (in Japanese with English summary).

Sameshima, R., Hirota, T., Hamasaki, T., Katou, K., and Iwata, Y., 2008: Meteorological observations system at the National Agricultural Research Center for Hokkaido Region from 1966. Misc. Pub. Natl. Agric. Res. Cent. for Hokkaido Reg., 66, 1-8.

Saxton, K. E., and Lentz, A. T., 1967: Antecedent retention index predict soil moisture. Proc. Am. Soc. Civil Eng. J. Hydraulic Div., 93, 223-241.

Shinoda, M., Yamaguchi, Y., and Iwashita, H., 2000: A new index of the Sahelian soil moisture for climate change studies. Proceedings of the International Conference on Climate Change and Variability - Past, Present and Future-, 13-17 September 1999, Tokyo, Japan, 255-260.

Wang, J. R., 1985: Effect of vegetation on soil moisture sensing observed from orbiting microwave radiometers. Remote Sens. Environ., 17, 141-151.

Ye, Z., and Pielke, R. A., 1993: Atmospheric parameterization of evaporation from non-plant-covered surfaces. J. Appl. Meteor., 32, 1248-1258. 


\title{
ルーチン気象観測データからの裸地面の蒸発効率の推定と 土㙴水分データを用いないパラメータ化
}

\author{
広田知良*・福本昌人** \\ $\left(\begin{array}{c}* \text { 農研機構北海道農業研究センター } \\ * * \text { 農研機構農村工学研究所 }\end{array}\right)$
}

要

約

バルク法による裸地面からの蒸発量を推定する場合, 蒸発効率は最も重要なパラメータとなる。本研究では, 10 日以上から数ヶ月程度の蒸発効率の期間平均值を, 顕熱と潜熱フラックスおよび土壌水分のデータを用いず にルーチン気象観測データから簡易に推定しパラメータ 化する方法を開発した。地温データがルーチン気象観測 データ (気温, 日射量, 降水量, 風速, 湿度等) と共に 観測されて, これらの日平均值の值が提供されるならば, 蒸発効率は簡易な地温推定モデルにより潜熱, 顕熱フラ ックスデータを用いなくても推定することができる。地温 推定モデルは地表面の熱収支式とバルク法, および日平 均地温を推定するための force-restore 法で構成されて いる。蒸発効率の推定期間は, 土壌の湿潤状態を反映
する降水量の条件によって 10 日程度から数ヶ月程度とな る。その際, 先行降雨指数は土壌水分データを用いない で, 土袞の湿潤状態を判定できる効果的な指標となる。 この先行降雨指数により蒸発効率を土壌の湿潤状態に応 じた適切な推定期間に分類することができる。蒸発効率 は先行降雨指数によって分類された期間の下での日平均 地温の推定值を観測值の差の二乗値の合計值が最小に なるように推定する。さらに, 裸地面の日平均地温と積 算蒸発量を標準的な気象観測データから推定することを 目的として, 10 日から数ヶ月平均の蒸発効率を降水量と 可能蒸発量の比からパラメータ化する手法を提案する。 キーワード：蒸発効率, 蒸発量, 地温, パラメータ化, 裸地 